\title{
VARIASI JARGON DALAM SUATU KOMUNITAS WARIA DI SALON RETHAH WILAYAH PONDOK BENDA

\author{
Amanda Rizky Amalia ${ }^{1}$, Antika Suri Tauladan ${ }^{2}$, Fani Aulia Sari ${ }^{3}$ \\ Universitas Pamulang ${ }^{1,2,3}$ \\ amandarizky126@gmail.com ${ }^{1}$, antikasuritaula@gmail.com², auliasarifani@gmail.com ${ }^{3}$
}

\begin{abstract}
Language has an important role in everyday human life in society. Jargon is a kind of language that is only used by certain communities as daily communication among its members. The jargon used by the transgender community is very interesting to understand because the jargon has its own form and meaning in its disclosure and can find out how the variety of jargon-shaped language used by transgenders in hiding their secrets so as not to be known by the public. It is evident that not all users of other languages understand the jargon. In this study, the researchers analyzed the jargon used by the waria community in the salon. This study aims to determine the jargon and describe and understand the meaning of the jargon used by the transgender community in interacting orally. The source of the research data was obtained from the subject, namely the transgender women who worked at the Retah salon in Pamulang, who used jargon in their daily communication with transgender women and sometimes with their customers. The method used in this study is a qualitative descriptive method, which describes and conveys data objectively. Describe the jargon terms of transgender language as the object of research. The data collection technique used is observation or see and note. The result of this research is the jargon used by waria in the form of transgender language vocabulary. Based on the results of the data analysis, it was found that 20 pieces of jargon used by transgender women in the salon were akika, rapose, capcus, endang gurindang, ink, sekong, belenjong, cucok, metong, hamidah, lekong, sapose, capcay, begindang, bala-bala, sindang., lambreta, grasshopper, mesong, and mursida.
\end{abstract}

Keywords: Waria, Jargon, Vocabulary

\begin{abstract}
ABSTRAK
Bahasa memiliki peran penting bagi kehidupan manusia sehari-hari dalam masyarakat. Jargon adalah sejenis bahasa yang hanya digunakan oleh komunitas tertentu sebagai komunikasi sehari-hari di antara anggotanya. Jargon yang digunakan oleh komunitas waria sangat menarik untuk ditelitii karena jargon tersebut memiliki bentuk dan makna khusus dalam pengungkapannya serta bisa mengetahui bagaimana variasi Bahasa yang berbentuk jargon digunakan oleh para waria dalam menutupi rahasia yang dimiliki mereka agar tidak diketahui oleh masyarakat. Terbukti tidak semua pengguna bahasa lain memahami jargon tersebut. Dalam penelitian ini peneliti menganalisis jargon yang digunakan oleh komunitas Waria di salon. Penelitian ini bertujuan untuk mengetahui jargon dan mendeskripsikan serta memahami makna jargon yang digunakan oleh komunitas waria dalam berinteraksi secara lisan. Sumber data penelitian diperoleh dari subjek yaitu kounitas wariayang bekerja di rethah salon Pamulang yang kesehariannya menggunakan jargon dalam berkomunikasi denganantarwaria dan terkadang dengan pelanggannya. Penelitian ini menggunakan metode deskriptif kulitatif yaitu memaparkan dan menyampaikan data secara objektif. Mendeskripsikan istilah-istilah jargon yang digunakan waria sebagai objek penelitian. teknik pengumpulan data yang digunakan yaitu observasi atau simak dan catat. Hasil dari penelitian ini yaitu jargon yang digunakan oleh para waria dalam bentuk kosa kata bahasa waria. Berdasarkan hasil analisis data ditemukan jargon sebanyak 20 buah yang digunakan para waria di salon yaitu akika, berapose, capcus, endang gurindang,tinta, sekong, belenjong, cucok, metong, hamidah, lekong, sapose,capcay, begindang, bala-bala, sindang, lambreta, belalang, mesong, dan mursida.
\end{abstract}

Kata Kunci: Waria, Jargon, Kosakata

\section{PENDAHULUAN}

Bahasa merupakan media untuk berinteraksi yang digunakan oleh penutur dan mitra tutur, bahasa sendiri bersifat arbitrer atau mana suka yang berarti tidak ada keharusan bahwa bahasa tersebut harus memiliki arti. Selain itu bahasa digunakan sebagai alat untuk berinteraksi dan memahami satu sama lain yang artinya bahasa merupakan aktivitas sosial. Menurut Kridalaksana dan Djoko Kentjono (dalam Chaer, 2014:32) bahasa adalah sistem lambang bunyi yang arbitrer yang 
hanya digunakan oleh suatu keompok sebagai media untuk berinteraksi, sebagai identitas, berkomunikasi dan untuk bekerjasama.

Di setiap daerah pasti memiliki bahasanya masing-masing, sama halnya dalam suatu kelompok disuatu masyarakat yang pastinya memiliki bahasa masing-masing yang berfungsi sebagai identitas kelompok tersebut berdasarkan perilaku yang khas dari pengguna bahasa tersebut. Maka pada konteks ini pemakaian bahasa yang peneliti fokuskan yaitu penggunaan variasi bahasa jargon yang dipakai oleh kelompok waria di salon kecantikan yang berada di wilayah pondok benda.

Jargon yang digunakan oleh komunitas waria merupakan salah satu dari banyaknya variasi bahasa yang sering digunakan oleh masyarakat indonesia. Jargon sendiri merupakan kata-kata khusus yang dibuat dan digunakan oleh kelompok tertentu tetapi kata-kata tersebut tidak bersifat rahasia. Penggunaan jargon oleh waria di salon kecantikan pada awalnya tidak mudah untuk diterima masyarakat, namun intensnya pertemuan maka membuat masyarakat luar penasaran tentang jargon yang digunakan oleh kelompok waria tersebut, hingga pada akhirnya jargon yang digunakan oleh kelompok waria bisa diterima bahkan lazim digunakan oleh masyarakat luar.

Sebagai bahasa, Jargon biasanya memiliki dua bentuk dasar di dalamnya, yaitu bentuk dan makna. Bentuk terdiri atas bunyi, tulisan dan struktur. Dari bentuk, struktur jargon digunakan bervariasi seperti kata-kata umum yang biasa dijumpai dan diubah menjadi kata yang khusus. Sedangkan makna terdiri atas makna leksikal dan gramatikal.

Waria adalah seorang pria yang memiliki perilaku dan penampilan yang menyerupai wanita. Secara fisik waria adalah seorang laki-laki tetapi dalam mengekspresikan jati diri dan identitas gendernya sebagai perempuan. Ada tiga faktor yang menjadikan laki-laki menjadi seorang waria yaitu pertama, disebabkan oleh faktor biologis yaitu laki-laki tersebut memiliki hormon wanita yang dominan. Kedua, faktor psikologis yaitu iklim keluarga yang tidak harmonis mempengaruhi perkembangan psikologis anak dan yang ketiga, fakor sosiogenik yaitu lingkungan sosial yang memberikan dampak dan mendorong untuk melakukan yang menyimpang.

Penelitian mengenai jargon yang pernah dilakukan yaitu variasi jargon yang digunakan oleh komunitas waria di media sosial Facebook, penelitian ini ditulis oleh Jusmianti Garing Balai Bahasa Sulawesi Selatan dalam bentuk jurnal. Penelitian ini membahas tentang bagaimana penggunaan bentuk jargon yang digunakan oleh Kelompok waria pada media massa facebook, yang mengkaji tentang variasi bahasa dilihat dari segi aspek semantik dan bagaimana perubahan maknanya. Selanjutnya penelitian terdahulu yang berkaitan yaitu Jargon Dalam Tindak Tutur Waria PekerjaSalon Sandra Jalan Jawa Jember Dalam Interaksi Sosial, penelitian ini ditulis oleh Budi Utomo SMAN2 Jember. Pada penelitian ini membahas tentang ragam variasi bahasa salah satunya adalah penggunaan jargon oleh komunitas waria tersebut. Berdasarkan data yang dihasilkan bentuk jargon yang digunakan adalah jargon dalam bentuk kata, singkatan dan berbentuk kalimat. Selain itu 
ada juga penelitian yang pernah dillakukan adalah penggunaan jargon oleh komunitas banci di kota Padang, SumateraBarat. Penelitian tersebut merupakan skripsi yang ditulis oleh Iis Komarian pada tahun 2011. Hasil daripenelitian tersebut terdapat 34 data jargon yang mengalami perubahan makna. Jargon yang digunakan melibatkan waria yang bekerja di salon yang berada di kota Padang.

Peneliti memilih jargon yang digunakan oleh waria di salon dalam penelitian ini karena tidak banyak orang yang mau membahasa mengenai jargon yang digunakan oleh waria sebagai topik utama penelitian. Padahal jika kita kaji secara mendalam jargon yang mereka ciptakan dari bentuk kata yang umum menjadi khusus terbilang unik dan beragam yang memang menarik untuk dianalisis.

\section{LANDASAN TEORI}

Pada penelitian ini mengkaji bagaimana penggunaan jargon oleh komunitas waria di salon adalah Bahasa yang digunakan secara lisan, bahasa lisan sendiri berfungsi sebagai alat komunikasi dan interaksi sebagai mahluk sosial.Penggunaan bahasa lisan dapat menciptakan macam-macam variasai bahasa salah satunya adalah jargon. Maka, peneliti mengkaji jargon sebagai fokus utama pada penelitian ini.

1. Jargon

Menurut Chaer dan Agustina (2010:89) mendefinisikan Jargon sebagai variasi bahasa yang digunakan komunitas tertentu. Jargon sendiri berbentuk pernyataan yang tidak semua orang dapat memahaminya. Tetapi pada dasarnya pernyataan dalam jargon tidak bersifat rahasia, yang artinya jargon tersebut akan dipahami jika orang-orang di luar komunitas mau untuk mempelajarinya.

Jargon banyak diciptakan dan digunakan oleh banyak komunitas sosial. Mereka menciptakan Jargon yang tidak mudah dipahami dan bersifat khusus. Namun, tidak menutup kemungkinan masyarakat luas akan penasaran dan mulai mempelajari Jargon tersebut. Dari hasil pengamatan peneliti, dalam proses interaksi para waria mengacu pada penggunaan kosakata yang berbeda, lucu, unik, singkat dan terkesan aneh. Misalnya pada kata "Akika“ yang digunakan oleh para waria yang memiliki arti "Aku atau saya". Lalu ada kata "Lambreta" yang memiliki arti "Lambat". 
2. Kata

Menurut Keraf (1991: 53), kata merupakan kesatuan kecil setelah sebuah kalimat mengalami pembagian dan satuan tersebut memiliki ide pada makna kata tersebut. Pandangan lain dijelaskan oleh Djajakusma (1993: 33) bahwa kata merupakan bagian dari unsur kalimat yang bersifat terbuka dan dapat berdiri sendiri.

3. Makna

Makna menurut Kridalaksana (2001:1993) adalah tujuan pembicara untuk mempengaruhi pemahaman persepsi dari perilaku manusia atau suatu kelompok masyarakat. Memahami sebuah makna artinyamempelajari kata untuk dimengerti.

\section{METODE PENELITIAN}

Metode yanag digunakan ada penelitian ini adalah deskriptif kualitatif dengan sample yang sudah dikumpilkan lalu dianalisis sesuai dengan hasil data dilokasi. Metode deskriptif kualitatif merupakan metode yang mendeskripsikan bentuk kata dan tidak memakai urutan angka (Chariri, 2009).

Penelitian ini menggunakan teknik simak catat. Teknik simak adalah teknik penyaringan data dengan cara mendengarkan penggunaan bahasa yang dilakukan oleh narasumber ketika melakukan proses komunikasi. Teknik catat adalah teknik lanjutan dari simak yang artinya hasil data yang didapat dicatat dan dianalisis. Objek dari penelitian ini adalah komunitas waria di salon.

\section{PEMBAHASAN}

Berdasarkan hasil observasi peneliti mendapatkan 20 data. Dari data tersebut sering digunakan oleh waria sesuai dengan kondisi dan situasi penutur dan mitra tutur ketika berkomunikasi.

Tabel penggunaan bahasa waria di dalam salon:

\begin{tabular}{|l|l|l|}
\hline No. & \multicolumn{1}{|c|}{ Jargon } & \multicolumn{1}{c|}{ Arti } \\
\hline 1. & Akika & Aku atau Saya \\
\hline 2. & Berapose & Berapa \\
\hline 3. & Capcus & Pergi \\
\hline 4. & Endang Gurindang & Enak sekali \\
\hline
\end{tabular}




\begin{tabular}{|l|l|l|}
\hline 5. & Tinta & Tidak \\
\hline 6. & Sekong & Sakit \\
\hline 7. & Belenjong & Belanja \\
\hline 8. & Cucok & Cocok \\
\hline 9. & Metong & Mati atau meninggal \\
\hline 10. & Hamidah & Hamil \\
\hline 11. & Lekong & Laki-laki \\
\hline 12. & Sapose & Siapa \\
\hline 13. & Capcay & Cape \\
\hline 14. & Begindang & Begitu \\
\hline 15. & Bala-bala & Bayar \\
\hline 16. & Sindang & Sini \\
\hline 17. & Lambreta & Lama \\
\hline 18. & Belalang & Beli \\
\hline 19. & Mesong & Mau \\
\hline 20. & Mursida & Murah \\
\hline & Jargon beras & Wara \\
\hline
\end{tabular}

Jargon berbentuk kata sangat sering digunakan oleh komunitas waria pada saatberkomunikasi antar sesama waria. Kata tersebut dilontarkan dengan tujuan tertentu utamanya untuk menyembunyikan masalah yang sebenarnya. Jargon yang berbentuk kata biasanya digabungkan dengan pilihan kata pada umumnya. Namun jika dilihat secara keseluruhan gabungan kata tersebut terdiri dari kata-kata jargon. Ketika sesama waria menggunakan variasi jargon dihadapan masyarakat umum untuk menyebunyikan maksud yang ingin disampaikan misalkan seperti dalam kalimat : "Akika capcus ya bo" (aku pergi dulu ya ) yang artinya waria tersebut sedang berbicara dengan seseorang di dekatnya.

Pada kalimat "Belalang dimandose?" (beli dimana?), waria menggunakan kalimat tanya tersebut ketika berbicara kepada sesama antar waria. beda halnya jika ia bertanya dengan pelanggan salon yang bukan merupakan komunitasnya, pelanggan salon tersebut tidak dapat memahami maksud dari pertanyaan waria tersebut karena pertanyaan waria tersebut sudah dalam bentuk jargonhanya dapat dipahami oleh sesama komunitas atau kelompoknya, di luar komunitasnya bahasa waria tidak dapat dipaham secara mendalam.

Komunitas waria juga tidak setiap saat menggunakan bahasa tersebut. Dalam interaksi seharihari baik dengan sesama waria ataupun dengan masyarakat umum, waria sering juga menggunakan bahasa sehari-hari pada umumnya. Pemakaian bahasa unik itu digunakan ketika situasi tertentu saja, 
salah satunya ketika ada beberapa orang didekatnya memang mengerti bahasa tersebut meskipun seseorang tersebut bukan waria atau bahasa ini juga digunakan pada saat posisi waria terancam oleh lingkungan sehingga mendorong para waria untuk berkomunikasi yang tidak dipahami orang-orang disekitarnya. Adapun hal yang mempengaruhi pemakaian bahasa waria ini salah satunya adalah karena ada waktu dan tempat, artinya bahasa ini tersebar dan tumbuh karena ada waktu untuk menuturnya juga ada wadah yang memfasilitasi para penutur ini untuk berkomunikasi nyata dengan bahasa ini. Di kampung parakan sendiri, para waria yang memiliki salon biasanya menggunakan bahasa tersebut untuk mewadahi eksistensinya.

\section{KESIMPULAN}

Berdasarkan hasil penelitian yang dilakukan, dapat disimpulkan penggunaan bahasa waria di salon merupakan variasi bahasa yang hanya bisa digunakan oleh kelompok waria saja. Penggunaan kosakata bahasa waria masih terbatas dan diperkirakan akan selalu mengalami perkembangan sesuai dengan kebutuhan yang diinginkan oleh komunitas waria dalam menyampaikan sesuatu. Jumlah penggunaan kosakata tersebuut masih minim dan belum dapat mewakili sepenuhnya dalam mengungkapkan gagasan, perasaan, dan sebagainya. Dari kedua kalimat yang dicontohkan dalam bahasa waria dinyatakan, bahwa kalimat-kalimat yang digunakan dalam percakapan tidak terikat pada situasi resmi, melainkan dalam situasi non formal atau tidak resmi.

\section{SARAN}

Berdasarkan penelitian yang telah dilakukan, maka peneliti berharap penelitian dibidang sosiolinguistik ini dapat menambah wawasan dan dijadikan sebagai pedoman dalam merumuskan masalah baru, khususnya hal yang berkaitan mengenai variasi jargon dan perlu dilakukan kajian lebih mendalam agar para pembaca dapat memahami lebih banyak variasi mengenai jargon.

\section{DAFTAR PUSTAKA}

Abdan, T. K. (2020). analisis pemakaian varian bahasa slang pada remaja desa kalinusu: kajian sosiolingusitik. Jurnal SEMANTIKA, Volume 1, No. 02, Maret 2020, 1-11.

Garing, j. (2017). Penggunaan jargon oleh komunitas waria di jejaring sosial 'facebook'. . Ranah, Volume 6, Nomor 1, Juni 2017, 9.

Jumianti, I. d. (2015). Jargon bahasa waria suatu kajian pragmatik. jurnal konfiks, Vol 2, No 2 (2015), 133-142.

Oktavia, w. (2018). Variasi jargon chatting whatsapp grup mahasiswa tadris bahasa indonesia. Jurnal KATA: Vol. 2, No. 2, Oktober 2018, 317-325.

Utomo, B. (2021). Jargon dalam tindak tutur waria pekerja salon Sandra jalan jawa jember dalam interaksi sosial. JURNAL GURU INDONESIA | Vol: 1 No: 1 Tahun 2021, 34-42.

Wakari, R. B. (2017). Penggunaan Jargon di Kalangan Waria Kota Bitung. Kajian Linguistik, Tahun IV, No.4, April 2017 